\title{
Basic Study on the Implementation of Outpatient Referral of BPJS Health Members in the First Health Facility at Makassar
}

\author{
Erni Febrianti ${ }^{1}$; Amran Razak; Siti Haerani ${ }^{2}$ \\ ${ }^{1}$ Department of Administration and Health Policy, Faculty of Public Health, Hasanuddin University, Indonesia \\ ${ }^{2}$ Department of Management, Faculty of Economics and Business, Hasanuddin University, Indonesia
}

http://dx.doi.org/10.18415/ijmmu.v6i5.1175

\begin{abstract}
The health insurance program in Indonesia shows efforts to continue to be optimized, one of which is through the implementation of a tiered referral system starting from the First Level Health Facility (FKTP). The purpose of this study was to determine the implementation of BPJS Health Outpatient referral at First Level Health Facilities (FKTP) in Makassar City. In this study using a mixed method, the population in this study was 146 people with 60 samples drawn. Quantitative data analysis namely univariate analysis, bivariate analysis and multivariate analysis used in this study is logistic regression analysis. While qualitative data analysis includes organizing / structuring data, conducting coding and categorizing, looking for patterns and research propositions, interpreting data, and evaluating interpretations. The results showed that there was an influence between health human resources on the implementation of outpatient referrals, there was an influence between facility facilities on the implementation of outpatient referrals. There is no influence between the availability of medicines on the implementation of first-degree outpatient referrals for BPJS Health patients at FKTP in the city of Makassar. There is no influence between the understanding of health workers about the tiered referral system and the implementation of first-degree outpatient referrals for BPJS Health patients at FKTP in Makassar city.
\end{abstract}

Keywords: Health Insurance; Referral; Outpatient; BPJS Patients

\section{Introduction}

Health development is an integrated part of human resource development in realizing a developed and independent nation as well as physical and spiritual prosperity (Adisasmito, 2014). One measure that we can see that makes the nation included in the advanced category with a high degree of health. Indonesia actually has had a health system since 1982 through the National Health System.

The Health Social Security Administration Agency (BPJS Health) in Indonesia supports the implementation of an optimal health insurance program through the implementation of a tiered referral 
system from the First Level Health Facility (FKTP) to the Advanced Health Facility (FKTL) in accordance with medical needs, so that patients can seek treatment at the facility primary health care such as health centers, clinics or family doctors listed on the BPJS Health Participant Card (Wahyuddin, 2017).

This aims to avoid increasing referrals or accumulation of patients in the hospital as FKTL so that the division of tasks between medical staff in FKTP and FKTL does not synergize properly because there are diseases that should be addressed in the Community Health Centers (Puskesmas) without having to provide a referral to the Hospital.

Gate Keeper or referral filter according to (Abdullah et al., 2014) is a health service system in which Puskesmas play the role of primary health care providers who function optimally according to competency standards and can provide health services in accordance with medical service standards and are able to serve 155 diagnoses properly and complete.

Health referral is one of the programs in the health effort subsystem. While the goal of implementing referral policy is to provide health services to all walks of life based on shared responsibility between all health service units. So that this reference is expected to be able to provide more quality services in overcoming and improving the degree of public health Caesaria et al., 2018; Soeripto, 2019).

The existence of a referral system that is well implemented is expected to provide quality health services where the goals of the service can be achieved without having to use expensive costs. According to Taher (2013), there are still people who do not yet know the technicalities of getting services in accordance with BPJS Health regulations. People who will seek treatment at a government public hospital with a BPJS card must get a referral from a doctor, clinic / Puskesmas, or regional public hospital. People who come to the secondary hospital will be served if they have received a referral from primary health care, in accordance with Minister of Health Regulation No. 001/2012 About the Individual Health Services Referral System. This regulation was issued so that the National Health Insurance Program (JKN) could be implemented well.

Based on BPJS Health data as per Quarter III 2015 in Indonesia there were 152,173,216 or around $33.33 \%$ of BPJS patients referred from FKTP to FKTL from the total number of BPJS Health participant visits to FKTP as many as 3.5 million visits per month, while the condition was up to July year 2016 recorded 4,779,380 or $14.17 \%$ of BPJS patients referred from FKTP to FKTL out of a total number of 33,721,051 visits of BPJS participant patients to FKTP (Wahyuddin, 2017). While for Makassar City, based on data from the Makassar Branch Office BPJS 2018 for referral of First Level Health Facilities in Makassar City.

Based on these data, it can be seen that from 162 First Level Health Facilities (FKTP) in Makassar, which consist of Puskesmas, Clinics, and Individual Doctors, researchers see that the percentage of referrals in these FKTPs is still high. Where the data shows there are 60 FKTP $(37 \%)$ with a reference percentage above $15 \%$. Whereas the standard percentage of referrals provided by BPJS Health to FKTP in collaboration that is for specialist referrals with a maximum standard of $15 \%$ and for nonspecialist referrals with a maximum standard of $5 \%$.

This study looks further at what is the cause of the high number of referrals in Makassar City. Based on the results of previous studies at the Siko Community Health Center and the Ternate City Kalumata Community Health Center, the results showed that the Community Health Center has not performed its function as a gate keeper so that the referral implementation has not been running well, limited availability of medicines and even a vacancy and the completeness of supporting facilities for 
medical medical devices that and the officers' understanding of referral filter is good but in practice it does not follow the established rules (Abdullah et al., 2014).

In the research conducted in South Sulawesi, Southeast Sulawesi and West Sulawesi the results were obtained that for the referral system the people complained about the referral system because sometimes they were referred to distant hospitals even though there were hospitals that were located closer than where they lived and some officers in the puskesmas did not understand about the referral system with 155 cases of illness and often patients make the puskesmas as a place to request referrals (Maidin \& Palutturi, 2014).

Furthermore, the research conducted by (Mutia, 2015) found that the implementation of the referral system at the puskesmas could not be carried out properly, seen from the experience of the implementing staff regarding the referral system policy which was classified as poor, the availability of medical equipment and facilities was still minimal, and in the implementation process the handling of 155 cases of illness in Puskesmas still refers to cases that can still be handled in Puskesmas. Another previous study stated that the ineffectiveness of the referral system in Indonesia had an impact on the accumulation of patients in advanced health facilities resulting in the inappropriate use of skilled workers and sophisticated equipment and the declining quality of health services (Primasari, 2015). The purpose of this study was to determine the implementation of existing references at the First Level Health Facility (FKTP) in Makassar City, namely at the Puskesmas, Clinics and Individual Doctors. In this case the researchers conducted the initial data collection at BPJS Makassar City Health in 2018 which showed the highest referral to the FKTP in Makassar City.

\section{Methods}

In this study using a mixed method (Mixed Method) which is a combination method which is a research approach that combines or connects quantitative and qualitative research methods (Creswell, 2013). The chosen research location is FKTP in Makassar City where the selection of FKTP is by looking at preliminary data and ranking each FKTP which has the highest percentage of referrals.

The population in this study is the service providers namely all health workers in Tamalate Health Center, Kassi-Kassi Health Center, Batua Health Center, Hasanuddin Farma Chemical Clinic, Hertasning Farma Chemical Clinic, dr. Agnes Sentosa, and Dr. Anna Soeraidah Hamdany with a total of 146 health workers. The research uses the Slovin formula because in sampling, a total of 60 samples. Then additional FKTP key informants were 1 Head, 1 Doctor, 1 Pharmacist, and 1 Laboratory Officer.

Data processing is performed using a computer with the SPSS program for windows. Data analysis, namely univariate analysis, provides a description of respondent characteristics and the presentation of descriptive results through the frequency and distribution of independent and dependent variables, bivariate analysis and analysis. Multivariate analysis used in this study is analysis logistic regression. While qualitative data analysis includes organizing / structuring data, conducting coding and categorizing, looking for patterns and research propositions, interpreting data, and evaluating interpretations. 


\section{Results and Discussion}

Distribution of Respondents

Table 1. Distribution of Respondents by Availability of Health Human Resources at FKTP in Makassar City

\begin{tabular}{ccc}
\hline Human Resources for Health & Frequency $(\mathrm{n})$ & Percentage $(\%)$ \\
\hline Adequate & 47 & 78,3 \\
Inadequate & 13 & 21,7 \\
Total & 60 & 100,0 \\
\hline
\end{tabular}

Table 1. shows that the number of health workers at the First Level Health Facilities in Makassar City were of the opinion that the availability of HRH was adequate as many as $47(78.3 \%)$ respondents, while a small number of respondents felt inadequate as many as $13(21.7 \%)$ respondents.

Table 2. Distribution of Respondents Based on the Availability of Equipment Facilities at FKTP in Makassar City

\begin{tabular}{ccc}
\hline Tool Facilities & Frequency $(\mathbf{n})$ & Percentage $\mathbf{( \% )}$ \\
\hline Adequate & 42 & 70,0 \\
Inadequate & 18 & 30,0 \\
Total & 60 & 100,0 \\
\hline
\end{tabular}

Table 2. shows that health workers at the First Level Health Facilities in Makassar City, who were mostly of the opinion that the availability of Equipment Facilities were adequate were $42(70.0 \%)$ respondents, while a small proportion were inadequate as many as $18(30.0 \%)$ respondents.

Table 3. Distribution of Respondents Based on Availability of Medicines at FKTP in Makassar City

\begin{tabular}{ccc}
\hline Medicines & Frequency $(\mathrm{n})$ & Percentage $(\%)$ \\
\hline Adequate & 40 & 66,7 \\
Inadequate & 20 & 33,3 \\
Total & 60 & 100,0 \\
\hline
\end{tabular}

Table 3. shows that the number of health workers at the First Level Health Facilities in Makassar City were of the opinion that the availability of medicines was adequate as many as $40(66.7 \%)$ respondents, while a small portion were inadequate as many as $20(33.3 \%)$ respondents.

Table 4. Distribution of Respondents Based on Understanding of the Tiered Referral System at FKTP in Makassar City

\begin{tabular}{ccc}
\hline Understanding of the Tiered Referral & Frequency (n) & Percentage (\%) \\
System & & \\
\hline Enough & 50 & 83,3 \\
Less & 10 & 16,7 \\
Total & 60 & 100,0 \\
\hline
\end{tabular}


Table 4. shows that health workers at the First Level Health Facilities in Makassar City who were mostly of the opinion that the understanding of the tiered referral system was sufficient as many as 50 $(83.3 \%)$ respondents, while a small number thought it was still lacking as many as $10(16.7 \%)$ respondent.

Table 5. Distribution of Respondents Based on Understanding of the Tiered Referral System at FKTP in Makassar City

\begin{tabular}{ccc}
\hline $\begin{array}{c}\text { Understanding About 155 cases of illness } \\
\text { handled at FKTP }\end{array}$ & Frequency (n) & Percentage (\%) \\
\hline Enough & 41 & 68,3 \\
Less & 19 & 31,7 \\
Total & 60 & 100,0 \\
\hline
\end{tabular}

Table 5. shows that health workers at the First Level Health Facilities in Makassar City, who were mostly of the opinion that the understanding of 155 cases of disease handled in FKTP was sufficient as many as $41(68.3 \%)$ respondents, while a small number thought it was still lacking as much as 19 $(31.7 \%)$ respondents.

Table 6. Distribution of Respondents Based on the Implementation of Outpatient Referral to FKTP in
\begin{tabular}{ccc} 
Makassar City \\
\hline $\begin{array}{c}\text { Implementation of Outpatient } \\
\text { Referral }\end{array}$ & Frequency (n) & Percentage (\%) \\
\hline Well & 43 & 71,7 \\
Not good & 17 & 28,3 \\
Total & 60 & 100,0 \\
\hline
\end{tabular}

Table 6. shows that health workers at the First Level Health Facilities in Makassar City, who were mostly of the opinion that the implementation of outpatient referrals to FKTP in Makassar City was already good as many as $43(71.7 \%)$ respondents, while a small number thought it was still not as good as many as $17(28.3 \%)$ respondents.

Table 7. The Effect of Each Independent Variable on Dependent Variables on FKTP in Makassar City

\begin{tabular}{cc}
\hline Variable & Statistical Test Results (P Value) \\
\hline HRH Availability & 0,028 \\
Availability of Equipment Facilities & 0,018 \\
Availability of medicines & 0,133 \\
Understanding of the Tiered Referral System & 0,295 \\
Understanding of 155 Disease Cases Treated at FKTP & 0,001 \\
\hline
\end{tabular}

Based on the results of bivariate analysis using chi square previously it was known that all variables studied were the availability of $\mathrm{HRH}$, the availability of equipment facilities, the availability of medicines, the understanding of the tiered referral system, and the understanding of 155 cases of disease handled at FKTP that affected the referral implementation ambulatory care, namely the availability of $\mathrm{HRH}$, the availability of equipment facilities, and an understanding of 155 disease cases handled at FKTP. So that the variables that meet the requirements to proceed to multivariate logistic regression analysis are 
the availability of $\mathrm{HRH}$, the availability of equipment facilities, and an understanding of 155 cases of disease handled at FKTP. Next, a multivariate analysis will be conducted to determine the effect of the most influential independent variable on the dependent variable.

Multivariate analysis with logistic regression test was conducted to determine the effect of the independent variables jointly (simultaneously) on the dependent variable and determine which independent variable was the most dominant influence on the implementation of outpatient referrals in FKTP in Makassar City. The final model of the logistic regression equation to determine the variables that most influence the implementation of outpatient referrals in FKTP in Makassar City can be interpreted from the coefficient values as follows:

Table 8. Results of Multivariate Analysis with Logistic Regression the Effect of Independent Variables on Dependent Variables on FKTP in Makassar City

\begin{tabular}{clcccccccc}
\hline & & & & & & & & \multicolumn{2}{c}{$95 \%$ C.I.for EXP } \\
& Variable & B & S.E & Wald & df & Sig. & $\begin{array}{c}\text { Exp } \\
\text { (B) }\end{array}$ & Lower & Upper \\
\hline Step & HRH & 1,462 & 0,661 & 4,899 & 1 & 0,027 & 4,319 & 1,182 & 15,760 \\
$1^{\mathrm{a}}$ & Tool Facilities & 1,447 & 0,614 & 5,559 & 1 & 0,018 & 4,250 & 1,276 & 14,151 \\
& Disease case & 2,082 & 0,641 & 10,543 & 1 & 0,001 & 8,021 & 2,283 & 28,185 \\
& Constant & -5.329 & 1.460 & 13.317 & 1 & 0,000 & 0,005 & & \\
\hline
\end{tabular}

Table 8 shows that the variables that have $\mathrm{p}<0.05$ are HRH availability $(\mathrm{p}=0.027)$, availability of equipment facilities $(\mathrm{p}=0.018)$, and understanding of 155 cases of disease handled at FKTP $(\mathrm{p}=$ 0.001 ), which means statistically these variables have a joint influence on the implementation of outpatient referrals in FKTP in the city of Makassar. Based on these results, it can be seen that the final model of the logistic regression equation to determine variables that greatly affect the implementation of outpatient referrals in FKTP in Makassar is by looking at the value of Exp (B) (estimated value of oddsratio) or the exponent value of the coefficient of the regression equation formed, the highest is in the disease case variable, which is an understanding of 155 disease cases handled at FKTP which is a variable of the process that is 8.021 times that of other variables on the implementation of outpatient referral, with a $\mathrm{p}$ value $=0.001$. Then the second most influential variable is the HRH variable (the availability of health human resources) at 4.319 times that of other variables with a value of $p=0.027$.

\section{Effect of Health Human Resources (HRH) on the Implementation of Outpatient Referral}

From the results of the study showed that some respondents rated the availability of health human resources (HRH) as inadequate. Respondents who assess the availability of $\mathrm{HRH}$ are inadequate because of the FKTP representing Makassar City stating that with the large number of visits should be adjusted to the number of adequate health workers so that service to patients can run well and cut the queue so long that patients and their families do not wait too long to be served by health workers. Based on the results of an interview with one of the health workers at FKTP in Makassar City.

In addition, there were several FKTPs who had duplicate work, for example the respondent served as a laboratory analyst but on the other hand also served as part of laboratory administration so that two jobs were completed by one health worker. However, most respondents think that the availability of Human Resources for Health ( $\mathrm{HRH})$ is adequate where there is a complete FKTP in filling positions 
according to their respective expertise so that there is no double division of work for one health worker so that the level of fatigue of health workers in serving patients can handled well.

This is in line with research conducted by (Purwati et al, 2017) at the Jember District Health Center stating that the health center lacks human resources, especially doctors. If the doctor can be fulfilled, the service will run well and can reduce the number of referral rates at the health center. Then in research conducted by (Ispandiyah \& Endartiwi, 2019) at FKTP Bantul Regency Yogyakarta which stated that the availability of human resources in providing referral services was good and with sufficient number of human resources so that there were no problems related to human resources in the implementation of tiered referral policies at FKTP.

Then in a study conducted (Nazriati et al., 2017) at Puskesmas doctors in Pekanbaru stated that as doctors who practice at the gates of health services, doctors at FKTP are required to be competent in screening and managing non-specialistic diseases in a complete manner. High referral rates are often associated with inefficiency, poor service delivery and failure to diagnose and high referral rates also have an impact on health financing.

\section{Effect of Tool Facilities on the implementation of outpatient referrals}

From the results of the study showed that some respondents considered the availability of inadequate equipment facilities. Respondents assess the availability of inadequate equipment facilities because of the FKTP representing Makassar City there is a Puskesmas that is still in the renovation stage so that it temporarily still occupies a school building so as to make services not optimal and some supporting facilities cannot function properly and some even do not function at all.

Respondents considered that the availability of equipment facilities was adequate because some of the tools were available at the FKTP and could be functioned well even though it was not as complete as a hospital but could already be used to provide services to patients visiting the FKTP.

In line with research conducted by (Alawi et al, 2015) at the Puskesmas in Sukabumi District, there is a relationship between the adequacy of medical equipment at the Puskesmas and the high referral of non-specialist cases. Once the importance of medical devices that must be in the health center because its function is very closely related to the task of doctors in preventing, diagnosing, healing and alleviating diseases, treating sick people, restoring health to humans, and / or forming structures and improving bodily functions. The absence or lack of medical equipment will reduce and hinder the work of doctors in carrying out their work.

Likewise, research conducted by (Majid \& Lisnawaty, 2017) at the Perumnas Health Center in Kendari City stated that the availability of medical equipment facilities at the Perumnas Health Center was incomplete so that it was very influential in providing basic health services to BPJS participants and affected the referral rates at the Perumnas health center. Furthermore, also the research conducted by (Umami et al, 2017) at the Pandanaran Health Center and Gunungpati Health Center stated that the availability of medical equipment facilities at the Pandanaran Health Center and Gunungpati Health Center was in accordance with Permenkes number 75 of 2014. Then the research conducted by (Dosi et al, 2018) states that the basic aspects of the selection of referrals where patients who make a referral to the Bahteramas Hospital because the facilities and infrastructure of the referral location such as Puskesmas and District Hospitals are inadequate. As well as research conducted by (Hermiyanty et al, 2019) at the Singgani Health Center, East Palu Regency stated that with the availability of adequate health facilities, it can reduce the case of RJTP referral. 
Effect of availability of medicines on the implementation of outpatient referrals

From the results of research that has been done, it shows that some respondents assess the availability of medicines as inadequate. Respondents who assessed the availability of medicines were inadequate because from FKTP representing Makassar City stated that there were some drug stocks that were vacant and several types of drugs were not available in FKTP because the drugs provided at FKTP had already determined which types of drugs. But for respondents who consider that the availability of medicines is adequate because some of the medicines needed are already available at the FKTP and are also disciplined in carrying out drug stocks. The results of interviews with health workers regarding the availability of drugs.

The results of this study are in line with research conducted by (Umami et al., 2017) which states that the availability of medicines in the Pandanaran Health Center and Gunungpati Health Center is in accordance with Fornas but the limitations that cause difficulties for doctors and patients but do not affect referrals. Likewise with the interview conducted with one of the other respondents.

However, this study is not in line with research conducted by (Majid \& Lisnawaty, 2017) which states that the availability of medicines in the Perumnas Health Center is still incomplete and this affects the increase in referral numbers in the Perumnas Health Center in Kendari City.

The effect of understanding Tiered Referral System on the implementation of outpatient referrals

From the results of research that has been done, it shows that some respondents assess the understanding of tiered referral systems is still lacking. Respondents who assess the understanding of tiered referral systems are still lacking because of a number of FKTP representing Makassar, some respondents said that there was no sharing of the tiered referral system so we had to study for ourselves and some employees who were still in contract status did not really understand the tiered referral system because it was new how many months joined. But for respondents who considered that the establishment of a tiered referral system was good enough because every day health workers were inseparable from conducting patient referrals so that they would always be familiar with the implementation of the referral and referral flow so that an understanding of the tiered referral system was well known. Currently for the implementation of the referral itself already uses an online-based referral system so that every patient who will be referred on that day can choose the FKTL option that appears on the online system on the computer on that day.

This study is in line with research conducted by (Alawi et al., 2015) at the Puskesmas in Sukabumi District which states that after being analyzed by the chi-square test there is no relationship between the doctor's knowledge of the gatekeeper concept and non-specialistic case referral in the tiered referral system to high rates reference. This is consistent with interviews conducted with respondents.Also in research conducted by (Abrahim et al., 2015) which states that the referral system among health facilities in Ethiopia is used by a small proportion of patients, indicating that the intended connections between health posts, health centers, and hospitals may need to be strengthened to improve efficiency national primary care.

Then in a study conducted by Senitan et al., (2017) states that a well-managed referral system is very important in assisting the management of type 2 diabetes in Saudi Arabia but the results of the study found that patient requests are not necessary for referral, referral letters are not structured, and unclear deployment guidelines for reference. Furthermore, research conducted by AlGhamdi et al., (2015) highlights some of the deficiencies in the effectiveness of the referral system in PHCC from the viewpoint of doctors working in secondary government hospitals in Taif. 
However, this study is not in line with research conducted by Doaly et al., (2018) which states that the incomprehension of some doctors about referral and limitations of drugs in primary facilities so that patients who have been referred back, go back to the hospital to get the drugs needed so that it increases referral rate at RSUD.

Influence of understanding of handling 155 cases of illness served in the Puskesmas / FKTP

From the results of research that has been done, it shows that some respondents consider the availability of inadequate equipment facilities. Respondents assess the availability of inadequate equipment facilities because of the FKTP representing Makassar City there is a Puskesmas that is still in the renovation stage so that it temporarily still occupies a school building so as to make services not optimal and some supporting facilities cannot function properly and some even do not function at all. But for respondents who consider that the availability of equipment facilities is adequate because some tools are available at the FKTP and can be functioned well even though it is not as complete as a hospital but can already be used to provide services to patients visiting the FKTP.

The results of this study are in line with research conducted by Faulina et al., (2017) which states that the diagnosis of many diseases is referred mainly to Diabetes Mellitus without complications or with complications and essential hypertension which is FKTP's competence so that it makes a contributor to the reference number. However, this study is not in line with research conducted by Alawi et al., (2015) at the Sukabumi District Health Center which states that after analysis with the chi-square test there is no relationship between physician knowledge about non-specialistic cases and non-specialistic case referrals, this is shown by $\mathrm{p}$ value 0.733 .

\section{Conclusion}

There is an influence between health human resources on the implementation of first-degree outpatient referrals of BPJS Health patients at FKTP in Makassar city. There is an influence between tool facilities on the implementation of first-level outpatient referrals for BPJS Health patients at FKTP in Makassar city. There is no influence between the availability of medicines on the implementation of firstdegree outpatient referrals for BPJS Health patients at FKTP in the city of Makassar. There is no influence between the understanding of health workers about the tiered referral system and the implementation of first-degree outpatient referrals for BPJS Health patients at FKTP in Makassar City. 


\section{References}

Abdullah, F., \& Kandou, A.G.D. (2014). Analisis Pelaksanaan Rujukan Rawat Jalan Tingkat Pertama Peserta Program Jaminan Kesehatan Nasional (JKN) di Puskesmas Siko dan Puskesmas Kalumata Kota Ternate Tahun 2014, JIKMU, 5(2), 221-237.

Abrahim, O., Linnander, E., Mohammed, H., Fetene, N., \& Bradley, E. (2015). A patient-centered understanding of the referral system in ethiopian primary health care units. PloS one, 10(10), e0139024.

Adisasmito, W. 2014. Sistem Kesehatan. Jakarta: Rajawali Pers.

Alawi, M., Junadi, P., \& Latifah, S. N. (2017). Analisis Faktor-Faktor yang Berhubungan dengan Tingginya Rujukan Kasus Non Spesialistik Pasien Jaminan Kesehatan Nasional pada Puskesmas di Kabupaten Sukabumi Tahun 2015. Jurnal Ekonomi Kesehatan Indonesia, 2(1).

AlGhamdi, O. M., Al-Malki, B. M., Nahhas, A. E., \& Al-Malki, A. D. (2015). Rate of referral from primary health care to secondary health care among governmental hospitals in Taif governorate, KSA. International Journal of Medical Science and Public Health, 4(10), 1457-1464.

Caesaria, R., Sulistiadi, W., Lestari, A. D., \& Murtafia, F. (2018). Policy Analysis toward the Effectiveness of Implementation of a Referral Program on Indonesia Social Health Insurance: Lessons Learned from Depok City Hospital in Indonesia. KnE Life Sciences, 4(1), 222-228.

Creswell, J.W. (2013). Research Design, Pendekatan Kualitatif, Kuantitatif, dan Mixed (Ketiga). California.SAGE.

Doaly, G., Kandou, G. D., \& Abeng, T. D. (2018). Analisis Pelaksanaan Sistem Rujukan Pasien di Rumah Sakit Umum Daerah (RSUD) Dr. Sam Ratulangi Tondano Kabupaten Minahasa. Community Health, 2(5).

Dosi, N. P., Suhadi, S., \& Lisnawaty, L. (2019). Studi Pelaksanaan Sistem Rujukan Berjenjang Di Rumah Sakit Bahteramas Tahun 2018. Jurnal Ilmiah Mahasiswa Kesehatan Masyarakat, 3(3).

Faulina, A. C., Khoiri, A., \& Herawati, Y. T. (2017). Kajian Pelaksanaan Sistem Rujukan Berjenjang dalam Program Jaminan Kesehatan Nasional (JKN) di UPT. Pelayanan Kesehatan Universitas Jember. IKESMA, 12(2).

Hermiyanty, H., Wandira, B. A., \& Nelianti, F. (2019). Implementasi Rujukan Pasien Jaminan Kesehatan Nasional (JKN) Badan Penyelenggara Jaminan Sosial (Bpjs) Di Puskesmas Singgani Kecamatan Palu Timur Kota Palu. Healthy Tadulako Journal (Jurnal Kesehatan Tadulako), 5(1), 32-38.

Ispandiyah, W., \& Endartiwi, S. S. (2019). Pelaksanaan Kebijakan Rujukan Berjenjang Bagi Peserta BPJS Kesehatan. Wawasan Kesehatan: Jurnal Ilmiah Ilmu Kesehatan, 5(1).

Maidin, A., \& Palutturi, S. (2016). Kajian Implementasi Jaminan Kesehatan Nasional Lintas Provinsi (Sulawesi Selatan, Sulawesi Tenggara, Sulawesi Barat) Tahun 2014. Jurnal Kebijakan Kesehatan Indonesia: JKKI, 5(3), 96-100. 
Majid, R., \& Lisnawaty, L. (2017). Studi Pelaksanaan Sistem Rujukan Rawat Jalan Tingkat Pertama (Rjtp) Padapeserta Bpjs Kesehatan di Puskesmas Perumnas Kota Kendari Tahun 2016. Jurnal Ilmiah Mahasiswa Kesehatan Masyarakat, 2(5).

Mutia, D. (2015). Analisis Pelaksanaan Rujukan Peserta Jaminan Kesehatan Nasional (JKN) Pada Puskesmas Susoh dan Puskesmas Blangpidie di Kabupaten Aceh Barat Daya. Master's thesis.

Nazriati, E., Iskandar, S., \& Rinawan, F. (2017). Evaluasi pelatihan dokter puskesmas sebagai upaya peningkatan pengetahuan tentang rujukan penyakit non-spesialistik di Pekanbaru. Majalah Kedokteran Andalas, 40(2), 71-81.

Primasari, K. L. (2015). Analisis Sistem Rujukan Jaminan Kesehatan Nasional RSUD. Dr. Adjidarmo Kabupaten Lebak. Jurnal Administrasi Rumah Sakit Indonesia, 1(2).

Purwati, E. I. I., Nuryadi, N., \& Herawati, Y. T. (2017). Pengambilan Keputusan dalam Pelaksanaan Rujukan Puskesmas sebagai Fasilitas Kesehatan Tingkat Pertama (Decision Making in the Refferal Implementation at Public Health Center as First Level Health Facility). Pustaka Kesehatan, 5(2), 231-238.

Senitan, M., Alhaiti, A., Gillespie, J., Alotaibi, B., \& Lenon, G. (2017). The referral system between primary and secondary health care in Saudi Arabia for atients with Type 2 Diabetes: A Systematic Review. Journal of Diabetes Research, 2017, 1-8.

Soeripto, N. D. (2019). The Implementation of Clinical Procedures In The Vertical Referral System In A Primary Healthcare Center. Jurnal Administrasi Kesehatan Indonesia, 7(1), 73-80.

Taher, A. (2013). Kesiapan Implementasi JKN dan peran Fakultas Kedokteran dalam Penyediaan Dokter Layanan Primer. Materi Seminar Kesiapan Implementasi JKN di Provinsi Jawa Barat Bandung, 21 Desember 2013. Direktorat Jenderal Bina Upaya Kesehatan Kementrian Kesehatan Republik Indonesia.

Umami, L.S., Soeharto, B.P., \& Wulandari, D.R. (2017). Analisis Pelaksanaan Rujukan Rawat Jalan Tingkat Pertama Peserta BPJS di Puskesmas. Jurnal Kedokteran Undip, 6(2).

Wahyuddin, M. (2017). Faktor yang Mempengaruhi Peningkatan Rujukan Pasien Rawat Jalan Peserta BPJS Kesehatan di Wilayah Puskesmas Kota Poso Tahun 2017. Makassar: Tesis. Program Magister Administrasi Kebijakan Kesehatan Fakultas Kesehatan Masyarakat Universitas Hasanuddin.

\section{Copyrights}

Copyright for this article is retained by the author(s), with first publication rights granted to the journal.

This is an open-access article distributed under the terms and conditions of the Creative Commons Attribution license (http://creativecommons.org/licenses/by/4.0/). 